\title{
VALUATION STANDARDS FOR INSURANCE COMPANIES IN THE FINANCIAL THEORY
}

\section{Milan Hrdý, Eva Ducháčková*}

\begin{abstract}
This article aims to evaluate the research of the different published opinions on the insurance company valuation, to analyse them and to judge their use in practice. The process of the valuation of the insurance company is very complicated and there are not many theoretical studies concerning this problem. The valuation of insurance companies should take into account the specifics of insurance activities and should look for the optimal approach. There were different approaches available - the income approach, the market comparison approach, the assets-based approach and the Bond Pricing Model. They can be combined and so there can be created different types of models. The two most important models of Massari, Gianfrate and Zanetti (2014) and Hrdý, Ducháčková (2014) were analysed and compared. Both models are applicable in practice. For the final valuation standards it could be recommended to use minimum of two methods of valuation or one of the two in detailed analysed models.
\end{abstract}

Keyword: valuation, insurance company, standards, models

JEL Classification: G32, G22

\section{Introduction}

Valuation of insurance companies is a very interesting field of valuation, which offers large possibilities for research activities that could be then used in the valuation practice as recommended procedures on the basis of the valuation standards. These standards are necessary because there are great differences among different experts opinions made by different appraisers during the valuation process of an individual insurance company. The reason for this relatively attractive field of research is the fact that valuations of insurance companies were firstly systematically analysed in the Czech Republic at the theoretical level at the turn of 2009 and 2010 years in the articles published in professional journals, for example Hejduková (2009), Hrdý, Ducháčková (2010, 2011) or Hejduková (2010). Also abroad, a very little attention is paid to this problem and the valuation procedure is very often based on general principles which are known from the practice of valuation of enterprises or generally from the valuation of financial institutions. There is no single methodology presented on this issue, even though there are considered basic approaches known from the valuation of enterprises such as income approach, market comparison method and assets-based valuation.

* Milan Hrdý, Faculty of Finance and Accounting, University of Economics in Prague, Czech Republic (hrdy@vse.cz);

Eva Ducháčková, Faculty of Finance and Accounting, University of Economics in Prague, Czech Republic(duchack@vse.cz).

This paper was prepared with the institutional support of the Faculty of Finance and Accounting University of Economics in Prague, Grant No. IP 100040. 
The valuation standards for insurance companies could represent some basic instructions how to act, but they could maintain the application of a subjective approach especially when it comes to risk evaluation, the estimation of the future market potential, and so forth. The identification of these valuation standards consists in the projection of the particularity of insurance companies into the valuation approaches known for enterprises. As with enterprises, the valuation procedures for insurance companies will be based on a detailed financial analysis. The goal of such analysis will be to assess the financial health of the insurance company and to prepare a foundation for the financial plan and for the confirmation of the sustainability of the insurance company on a going-concern principle. National banks or regulators usually publish data all over the whole sector of insurance companies which can be then compared to data of the insurance company being valued. Three basic approaches known for the valuation of enterprises such as the income approach, the assets-based approach and the market comparison approach are realized, but with some necessary adjustments respecting the specific of financial institutions and mainly of insurance companies. Also some specific approach known from the valuation of commercial banks called the Bond Pricing Model is used. The most important role plays of course the income approach, but also the market comparison approach has its position. On the contrary, the applicability of the assets-based valuation is very limited and it cannot be recommended for the valuation of an insurance company as a business entity, although it can be applicable for the valuation of individual assets of an insurance company and for accounting and tax purposes. When it comes to valuation by the market comparison method, the procedure is actually very similar to that used in the valuation of enterprises. The market comparison method uses the different multipliers and also must respect possible different approach to risk management in the insurance company being valued and in the insurance company being compared. This has significant impact on the value of the reported annual income, which is subject to comparison. Especially as of late, constant tightening and unification of some issues related to risk on an international level, e.g. in the Solvency II system, have been taking place. This leads to the approximately resembling risk management including the financial reserves. For the purpose of using of the income approach of valuation it is necessary to realize that we talk about the removable net income and the dividend-paying potential, not about the free cash flow as it is in case of enterprises. In case of planning the income obtained from the individual activities of insurance companies the market will have to be thoroughly divided into segments. It is also necessary to be able to forecast the future development of the market in each segment and the position of the insurance company. The income approach is identically as in case of enterprises realized in two phases where the first phase represents a period where a realistic plan is possible to prepare. The second phase represents the so called the ongoing value. The identification of the discount interest rate plays also an important role in case of the income approach and this discount interest rate is identified on the basis of the cost of equity which is used also in case of valuation of other financial institutions.

The different approaches above-mentioned could be also used and combined in different valuation models and procedures which can represent some different adjustment of the basic approaches or their combination. If there are some procedures and models, it is useful to judge them and to show their strengths and weaknesses and their possible application in practice. So the aim of this article is to elaborate and research different 
published opinions on the insurance company valuation, to analyse them and to judge their possible use in practice.

The methodology used would be based on some analyses of these opinions, on their comparison and finally on the final synthesis which could lead to the judgement if the valuation standards for the insurance companies do matter. The structure of this paper is based on the presentation of the different procedures and models which were proposed in previous publications and then on the presentation of the most important models published by Hrdý, Ducháčková (2014) and by Massari, Gianfrate and Zanetti (2014). The most important attention is paid to the comparison of these two models. Finally, all the models and procedures are analysed and judged for their use in practice. Also the model of Hrdý, Ducháčková (2014) could be adjusted according to these conclusions.

\section{Different Model Approaches to the Valuation of Insurance Companies}

Firstly, the different models based on the added value of insurance company were very often used. These models are represented mainly by the Embedded Value Indicator determined according to international guidelines. This model specifies the value of an insurance contract portfolio and is based on Adjusted Net Present Value of insurance company and on the actual value of future profits of the existing insurance portfolio of both life and nonlife insurance. The final formula is the following (Hrdý, Ducháčková, 2011):

$$
E V=P V F P+A N A V
$$

where $E V \quad$ Embedded Value,

PVFP Present Value of Future Profits,

ANAV Adjusted Net Asset Value.

This Embedded Value is very often used for measuring the performance of an insurance company and there is the question, if it is useful for the purpose of the valuation of the insurance companybasedontheview of the externalappraiser. However, thepresentvalue ofappropriately adjusted future profits will be the base for the income valuation of the insurance company. In reality this model is the combination of the assets-based approach and the income approach. Also Net Asset Value will be one of the components of Bond Pricing Model which will be presented later.

The next model based on the same principle is called Bangert Model or extended Embedded Value Model. This method has been adopted from the foreign literature (Antill, 2005; Damodaran, 2009; Cutler, 2005) and was presented in the Czech Republic by Králík, (2007, p. 79):

$$
L V=S N A+B_{I F}
$$

where $L V$ Layered Value,

SNA Sum of Shares of the Founding Capital Held by Individual Shareholders,

$B_{I F} \quad$ Market Power of the Insurance Company.

According to Králík (2007), the market power of an insurance company is equal to the "current value of the profits gained from insurance contracts that have already been executed". This approach, however, is only an adjustment of the classic Embedded Value 
Model and so cannot be considered a method suitable for the valuation of insurance companies and can be used mainly for measuring its performance. Not even the extended layered method, which extends the classic layered method by goodwill, does not solve the problem. The basic formula is the following (Králík, 2007):

$$
L V=S N A+B_{I F}+\text { goodwill }
$$

The consideration of the value of goodwill complicates the situation even more, because the process of determining goodwill is very complicated and complex and includes especially the management system of the insurance company and synergic effects, if they exist. At the same time Králík (2007) argues that "values in expert opinions and the actual value offered for a particular insurance company being valued may be also the result of differences in the understanding of goodwill by either party". At the same time, it is not possible to approve these differences in the reported values of an insurance company or another financial institution, because of their being caused by differences in the understanding of goodwill.

There are certain attempts of identifying the added value $\left(V A_{t}\right)$.

For example Králík (2007) offers the following equation:

$$
\begin{gathered}
V A_{t}=\text { Interest Accrued on the Net Asset Value }+ \text { Contribution of the Market Power } \\
\text { of the Insurance Company }+ \text { Contribution of the Recently Made Sales }+ \\
\text { Capital Adjustments }+ \text { Experience Newly Gained by the Insurance } \\
\text { Company from the Market. }
\end{gathered}
$$

If we were trying to evaluate the models listed above, it should be noted that their use is particularly suitable for the purposes of determining the performance of an insurance company and not for purposes of external evaluation. On the other hand, some parts can be used in other valuation models.

The models or procedures for valuation of insurance companies are specified in the foreign literature Miller (1995), Rezaee (2001), or Damodaran (2009) only marginally and this literature focuses on the common issue of valuation of financial institutions. Damodaran (2012, p. 596) offers some concrete information about insurance company valuation only by the following equation:

$$
\begin{gathered}
\text { Value of Equity = Equity Capital Invested Currently + Present Value } \\
\text { of Expected Excess Returns to Equity Investors. }
\end{gathered}
$$

Also this approach is relatively very general and it looks very similar to the basic Embedded Value Model and its principles can be used in the other models and procedures.

Ducháčková and Hrdý (2010) offered the two-phase income approach of valuation of the insurance company reflecting the specifics of insurance companies. This income approach is based on the dividend-paying potential which is derived from the profit per accounting period which is reduced by allocations to the legal reserves and statutory funds by necessary investment for the future profit growth and possibly by the capital adequacy ratio. According to Hrdý and Ducháčková (2011), net profit is the sum of the result of the nonlife insurance technical account, of the result of the life insurance technical account, of the yields on financial investments and of the other profit. The insurance costs and income tax are deducted from this sum. The final result is then adjusted by financial investment transfer 
account of both the life insurance and nonlife insurance technical account. Hejduková (2010) offers the relevant model for assets-based valuation of insurance companies. This model is based on either a direct or an indirect valuation method. The following formula may be used for the indirect method:

$$
S H_{\text {netto }}=A_{R H}-\left(C Z_{R H}-\left(R_{T}+N T R+V R\right) \times(1-d)\right)-P Z,
$$

where $\mathrm{SH}_{\text {netto }}$ Substance Net Value,

$A_{R H} \quad$ Reproduction Value Assets,

$C_{R H}$ Foreign Reproduction Value Resources,

NTR Surplus Technical Reserves,

$R_{T} \quad$ Hidden Reserves,

VR Buffer Reserve,

d Tax Rate,

PZ Contingent Liabilities.

To calculate the substance assets-based value by the indirect method, the following formula may be used (Hejduková, 2010):

$$
S H_{\text {netto }}=V K+\left(R_{T}+N T R+V R\right) \times(1-d)-P Z,
$$

where $\mathrm{SH}_{\text {netto }}$ Substance Net Value,

$V K \quad$ Equity in the Book Value,

$R_{T} \quad$ Hidden Reserves,

NTR Surplus Technical Reserves,

VR Buffer Reserves,

d Tax Rate,

PZ Contingent Liabilities.

These samples are very interesting, but it could be used only for the purpose of the assetsbased valuation and also for the Net Assets Value identification.

Hejduková (2009) brings up also an interesting idea for the valuation income approach when she "considers it to be more practical to start with the financial analysis and only then continue with the strategic analysis, although the financial analysis is more or less part of the strategic analysis as it is either included in its conclusion or follows it as a standalone chapter. The financial analysis forces us to think about the defining characteristics of insurance companies and its other characteristics without being limited to accounting and accounting statements, and it will help us comprehend various connections".

After the longer process of elaborating of the insurance companies' valuation Hrdý, Ducháčková (2014) offer some complex model of valuation of the insurance company in the following way:

$$
F V=\frac{1}{3} \times\left(\sum_{t=1}^{T} \frac{D C F S_{t}}{(1+i)^{t}}+\frac{O V}{(1+i)^{T}}\right)+\frac{1}{3} \times \frac{R O E}{i} \times N A V+\frac{1}{3} \times \frac{M V C}{B V C} \times B V,
$$

where FV Final Value of the Insurance Company,

DCFS t $_{t}$ Disposable Cash Flow Available to Shareholders,

$t \quad$ Individual Years of the First Phase,

T Time Length of the First Phase,

$i \quad$ Discount Interest Rate, 
OV Ongoing Value of the Insurance Company,

ROE Return on Equity,

NAV Net Asset Value,

MVC Market Value of a Comparable Insurance Company,

BVC Book Value of a Comparable Insurance Company,

$B V \quad$ Book Value of the Insurance Company.

This model is based on the combination of the income approach, Bond Pricing Model and market comparison method and each method is represented by the same share. It could be discussed if it is right because averaging different valuation methods could be in contradiction to common valuation practice represented by majority of academicians such as Damodaran (2009) or Mařík (2007). It is true that every method is based on different assumptions and it provides different information and solutions, but, on the other hand, the target of the valuation process is to identify the final market (real) value which is so close as possible to the real value. So the different assumptions of the different methods may not be in every case negative. And also the averaging of the different methods is not mostly recommended, but it is not forbidden. The solution of this situation could lie in the possibility to replace the same share of this three approaches by the other share according to the appraissal decision and according to the results of the fianncial analysis and according to the results of the so called analysis of internal and external factors. Also the omission some of these three methods could be possible. So the ajusted model could be the following:

$$
F V=a \times\left(\sum_{t=1}^{T} \frac{D C F S_{t}}{(1+i)^{t}}+\frac{O V}{(1+i)^{T}}\right)+b \times \frac{R O E}{i} \times N A V+c \times \frac{M V C}{B V C} \times B V,
$$

where $a, b, c-$ coefficients which represent the share of each of the three methods used. These coefficients may be in the interval of $<0,1>$ and their sum must be 1 .

Whereas the first addend represents the income approach of valution, the second one represents the so called Bond Pricing Model and the third one the market comparison method. Besides of MVC/BVC in case of market comparison method it is possible to use the different multiplies such as $\mathrm{P} / \mathrm{E}$ and, when comparable transactions are being used, it is the $\mathrm{M} / \mathrm{B}$ ratio or the ratio of annual net profits with the exclusion of extraordinary profits. Another possibility is to use the M/TBV (Market/Tangible Book Value) indicator or the ratio of dividend profits. If the relevant values are known, it is possible to recommend the average $\mathrm{P} / \mathrm{E}$ or $\mathrm{M} / \mathrm{B}$ values of a comparable company per certain period. Also Pláničková (Hejduková) (2014) works with some multiplies such as $\mathrm{M} / \mathrm{B}$ ratio or $\mathrm{D} / \mathrm{MV}$ or $\mathrm{MV} /$ premium.

Bond Pricing Model represents some special model used for the valuation of the financial institution which is based on the folowing equation (Hrdý, Ducháčková 2011):

$$
M V=\frac{R O E}{C O E} \times N A V
$$

where $M V$ Market Value of Insurance Company,

ROE Return on Equity,

COE Cost of Equity,

NAV Net Asset Value. 
This model is in fact simplified and parameterized income approach and represents the lower boundary of valuation whereas the income approach represents the upper boundary of valuation. The future potential of the insurance company in fact is not taken into account by Bond Pricing Model. The appraiser can then choose some value between both bondaries according to the results of the financial and other analyses.

The very important role in case of the income approach plays the identification of the discount interest rate. Weighted average costs of capital are not recommended as it is in case of the other financial institutions beacause of a relatively high share of debt in the capital structure of insurance company. So equity costs are used and there are different possibilities how to do it. The capital market line is relatively well-known and is based on the following formula (Hrdý, Ducháčková, 2014):

$$
\text { Equity Costs }=\text { Risk-Free Interest Rate }+ \text { Risk Surcharge } \times \beta
$$

The identification of $\beta$ coefficient could be relatively complicated, whereas the common approaches known for enterprises could be used in case of risk-free interest rate and risk surcharge identification according to Mařík (2007). To determine the $\beta$ coefficient for the area of insurance companies, known procedures must be used, such as the one by Damodaran (2002), or the country average of $\beta$ must be used. Hejduková (2010) mentions, that it is "more suitable to derive the beta by using the analogy method on comparable insurance companies. Considering the fact it is very hard to determine the foreign capital in commercial insurance companies, it is more practical to use the indebted beta when making the estimate by using the analogy method. This entails taking the beta from comparable insurance companies at their level of indebtedness and applying this beta directly to the insurance company being valued". The problem of the identification of coefficient $\beta$ is also discussed by Damodaran (2009). Some data concerning life and nonlife insurance companies were published, for life insurance companies in the USA 1.17, in Europe 1.20, and in developing markets 1.1 and for nonlife insurance companies in the USA it was 0.91, in Europe 0.95, and in developing markets 0.9 (Damodaran, 2009). The values of $\beta$ coefficient oscillate around the magic one which is in case of financial institutions valuation largely discussed. This value is by Damodaran (2009) recommended in case of maturity and stable banks and insurance companies. If the above mentioned statistics is considered a simple procedure for determining the $\beta$ coefficient for insurance companies could be derived in the following way (Hrdý, Ducháčková, 2014):

$$
\beta=1.2 \times \text { Share of Life Insurance }+0.95 \times \text { Share of Nonlife Insurance } .
$$

The final equation for determining the discount interest rate could be the following:

$$
i=i_{b}+(1.2 \times S L I+0.95 \times S N L I) \times R P+(-) R_{z},
$$

where $i_{b} \quad$ Risk Free Interest Rate,

SLI Share of Life Insurance,

SNLI Share of Non-Life Insurance,

RP Risk Premium,

$R_{z} \quad$ Risk Surcharge in a Particular Country. 
Some objections could arise, if the fact is taken into account that the level of risk of various insurance companies is individual and $\beta$ coefficient constantly varies in relation to development of economical and insurance market and in relation of different business condition of each insurance company. But the above mentioned equation is in fact some simplification which could help the appraiser the process of valuation because the probability that $\beta$ coeffient will be at the interval of 0.95 and 1.2 is relatively high. But this model cannot prevent the appraiser of identifying coefficient $\beta$ on an individual basis.

So the above mentioned sample could be substituted into the adjusted final valuation model:

$$
\begin{aligned}
& F V=a \times\left(\sum_{t=1}^{T} \frac{D C F S_{t}}{\left(1+\left(i_{b}+(1,2 \times Z P+0.95 \times N P) \times R P+(-) R_{z}\right)\right)^{t}}+\right. \\
& \left.+\frac{O V}{\left(1+\left(i_{b}+(1.2 \times Z P+0.95 \times N P) \times R P+(-) R_{z}\right)\right)^{T}}\right)+b \times \frac{R O E}{i} \times N A V+c \times \frac{M V C}{B V C} \times B V
\end{aligned}
$$

It is also necessary to take into account the ability of the the insurance company management to manage the insurance claim amount. The samples or approaches published (Potocký, Waldl, Stehlík, 2014) could be useful for the appraiser to judge this ability.

\section{The Massari, Gianfrate and Zanetti Valuation Model and Its Analysis}

The actual financial theory offers the two basic models for the valuation of the insurance companies, the so called Appraissal Value (Massari, Gianfrate and Zanetti, 2014) and the Relative Valution (Massari, Gianfrate and Zanetti, 2014) or (Nissim, 2013).

The appraissal model is based on a value measurement rooted in the actuarial techniques. The final sample is defined in the following way (Massari, Gianfrate and Zanetti, 2014, p. 209):

$$
\begin{gathered}
\text { Appraisal Value = Value of In-Force Business }+ \text { Adjusted Net Assets Value } \\
+ \text { Value of Future New Business. }
\end{gathered}
$$

It is necesssary to mention that the first two parts are the embedded value. This value was criticized by the authors, because it was useful only for the identification of the internal potential of an insurance company, not for the valuation from the external position. But in case there is the value of future business added to embedded value it has its own value for the external valuation.

Value of In-Force Business is defined as the difference between the present value of profits that will emerge from life insurance policies over time and the present value of cost of holding capital required to support the so called in-force business (Massari, Gianfrate and Zanetti, 2014). This costs are defined in the following way (Massari, Gianfrate and Zanetti, 2014, p. 211):

$$
\operatorname{COTS}_{t}=\sum_{i=t+1}^{n} \frac{M_{i-1} \times\left(K_{e}-i\right)}{\left(1+K_{e}\right)^{i}}
$$

where COTS Cost of Target Solvency Capital,

$i \quad$ Return from the Capital Allocated to the Existing Business Portfolio to

Meet the Solvency Capital Requirement, 
M The Capital allocated to the Existing Business Portfolio to Meet

The Solvency Capital Requirement,

$K_{e}$ Expected Return Risk Premium,

$t$ Time,

$n \quad$ The Expiry Date of the Portfolio Contracts with the Longest Maturity.

This model reminds the principle of the technical reserves in the insurance management. In general it is necessary for the valuation purpose to deduct from the expecting incomes the technical reserves or solvency capital for the purpose to cover risk from the future insurance claims.

The ANAV (Adjusted Net Asset Value) is the second part of the above mentioned model. There is a bit difference between the traditional $N A V$ used for example in the above mentioned Bond Pricing Model. The base of the $A N A V$ value is shareholder equity including the statutory capital and related surpluses and the assets valuation reserves. Unrealized capital gains or losses on assets classes which are not in real market values should be added or deducted (Massari, Gianfrate and Zanetti, 2014).

The last part of this model is represented by the value of the new business. These are defined as "open" businesses (Massari, Gianfrate and Zanetti, 2014), because they will try to generate further new business and growth by selling new policies to new and existing clients. The value of these future contracts is the "business goodwill" (Massari, Gianfrate and Zanetti, 2014) and it is the key component of the appraisal value. The business value measures the ability of an insurance company to get new clients or to buy new products to existing ones. According to Massari, Gianfrate and Zanetti (2014), this business goodwill has to be estimated by the external investors very often by their subjective assumption about the future potential of the insurance company. The Business Goodwill is defined in the following way (Massari, Gianfrate and Zanetti, 2014, p. 214):

$$
\begin{gathered}
\text { Business Goodwill }=m \times N e w \text { Business Value }(N B V), \\
m=\frac{P_{C}-E V_{C}}{N B V_{C}},
\end{gathered}
$$

where $m \quad$ Multiple $m$,

NBV New Business Value of $C$,

$E V_{C} \quad$ Embedded Value of $C$,

$P_{C} \quad$ Market Capitalization.

Having estimated $\boldsymbol{m}$ and knowing $\boldsymbol{N B} \boldsymbol{V}$ we are able to calculate the value of Business Goodwill.

The second valuation approach according to Massari, Gianfrate and Zanetti (2014) is the so called relative valuation. Although the name of this method is different, it is practically the same approach as the market comparison method according to Hrdý, Ducháčková (2011, 2014) or Hejduková $(2009,2010)$ or Nissim (2013). The relative value works also with the different multiples, for example P/E (Price-Earnings Ratio), P/BV (Price-Book Value) and $P / T B V$ (Price-Tangible Book Value), as the approach by Hrdý, Ducháčková (2011). But the new multiples are proposed by Massari, Gianfrate and Zanetti (2014), for example P/Premium or P/Embedded Value.

The multiple P/Premium is defined in a following way (Massari, Gianfrate and Zanetti, 2014, p. 216): 


$$
\frac{P}{\text { Premiums }}=\frac{1}{k_{e}} \times\left[(1-\text { Combined Ratio })+I L \times r_{i n v}\right]
$$

where $k_{e} \quad$ Cost of Equity,

IL Investment Leverage Coefficient,

$r_{i n v} \quad$ Investment Return Rate.

$$
\text { Premiums }=\text { Net Income }+ \text { Claims }+ \text { Operating Expenses }- \text { Income form Investments. }
$$

The multiple $P / E V$ is defined in a following way (Massari, Gianfrate and Zanetti, 2014, p. 216):

$$
\frac{P}{E V}=\frac{R O E V-g}{k_{e}-g}
$$

where $E V \quad$ Embedded Value,

ROEV Return on Embedded Value (Computing as Operating Earnings after taxes),

$k_{e} \quad$ Cost of Equity,

$g \quad$ Grow Rate.

The cost of equity for the discounted valuation model is defined here as the traditional model where the expected return equals risk free rate plus coefficient $\beta$ multiplied by risk premium. For $\beta$ is according to Massari, Gianfrate and Zanetti (2014) proposed the following formula:

$$
\text { Ajusted } \beta=\text { Observed } \beta \times 0.67+1.00 \times 0.33 \text {. }
$$

This formula takes into account also the reality that the large stable insurance companies tend to coeffient $\beta=1$. If to compare to the above mentioned sample by Hrdý and Ducháčková (2014) " $\beta=1.2 \times Z P+0.95 \times N P$ " it is clear that the sample by Massari, Gianfrate and Zanetti (2014) does not take into account the different systematic risk for the life and nonlife insurance. The life insurance is a bit more risky that nonlife insurance and for that reason it is necessary to take it into consideration in case of the identification of the $\beta$ coefficient.

The most important difference between Hrdý and Ducháčková model and Massari, Gianfrate and Zanetti (2014) model lies in the fact that Hrdý and Ducháčková put together three parts, but every of these parts is applicable on stand-alone basis for the purpose of valuation of insurance company. Massari, Gianfrate and Zanetti (2014), on the other hand, sum up values of different parts of the insurance company such as existing business, future business which looks relatively more correctly that it is in case of Hrdý and Ducháčková model (2014). But the correction of this model mentioned in the previous text a bit changed the situation in favour of this model because the appraiser has the opportunity to choose the share of each part of this model or even can one or two of the parts leave out. The most important role plays also the ability to use both models in practice. Adjusted Net Assets Value in case of Massari, Gianfrate and Zanetti (2014) model and Bond Pricing Model in case of Hrdý and Ducháčková model can be relatively very good applicable in practice because they are based on the actual data which are usually available. This is true even in case of Value of In-Force Business where information is also usually available. The problem in both models could consist in the income approach by Hrdý, Ducháčková and in Value of Future New Business by Massari, Gianfrate and Zanetti (2014), because it is necessary 
to work with some estimated future data. The application of the market comparison method in case of Hrdý, Ducháčková model or relative Valution in case of Massari, Gianfrate and Zanetti (2014) depends on the ability to find some comparable insurance company or comparable transactions. So the application of both models and procedures of valuation are relatively on the same level.

\section{Conclusion}

The aim of this article was to elaborate and research the different published opinions on insurance company valuation, to analyse them and to evaluate their use in practice. It is beyond all disputes that the valuation of the insurance companies is very complicated process with the different opinion on their solution. But, on the other hand, it is possible to highlight that if the individual models and approaches looks differently there is a lot of mutual components.

Even if Hrdý, Ducháčková (2014) offer the model with three parts with the Income Valuation, the valuation by Bond Obligation Model and the Market Comparison Approach and Massari, Gianfrate and Zanetti (2014) work with Appraissal Value and Relative Valuation, there are finally not so great differencies. It is neccessary to become aware of the fact that the Relative Valuation is in fact the Market Comparison Approach and that Appraissal Value obtains also $A N A V$, which comes out of the $N A V$ contained also in Obligation Pricing Model. The New Business Value according to the Massari, Gianfrate and Zanetti (2014) is some modification of the income approach according to Hrdý, Ducháčková (2014) because the Income Approach takes into consideration both the existing business and also the future business. Also the Embedded Value according to Hrdý, Ducháčková (2011) and Králík (2007) is the part of the Appraisal Value according to the Massari, Gianfrate and Zanetti (2014). Also the approach concerning Assets-Based Value Approach according to Hejduková (2009) makes the identification of $A N A V$ according to Massari, Gianfrate and Zanetti (2014) easier. Also the identification of the discount interest rate on the basis of the cost of equity did not show major difference between the conception of Massari, Gianfrate and Zanetti (2014) and Hrdý, Ducháčková (2014). Both approaches respect that the value of coeffient $\beta$ oscillates around value 1 and that is is necessary to respect this fact in the process of the indentification of the cost of equity which is used as the discount interest rate in the Income Valuation Approach. Massari, Gianfrate and Zanetti (2014) offer a larger extention of different multiplies for the purpose of the Relative Valuation (Market Comparison Valuation).

For the final valuation standards it could be recommended to use minimum of two methods of valuation and then identify the final valuation according to the results of the financial and strategic analysis and according to the future prospects of the insurance company being valued. It is posssible to use the Income Approach and Obligation Pricing Model by Hrdý, Ducháčková (2014) or the Appraissal Value which is the combination of the Embedded Value, ANAV and Income Approach representing by the New Future Business by Massari, Gianfrate and Zanetti (2014). The appraiser can also consider the use of the Market Comparison Methods or Real Valuation where there is a lot of different multiplies available.

There are also two valuation models available and each model could be used separately for the valuation process. Both models have their pros and cons and their use depends on the appraiser's possibility to obtain some necessary data. On the other hand, it is not recommended to use only the Embedded Value according to Králík (2007) or Massari, Gianfrate and Zanetti (2014). Also the Assets-Based Valuation, for example 
according to Hejduková $(2009,2010)$, is possible to use only in some specific cases such as the valuation for the tax or accounting purposes. The great advantage for the appraisal is the fact that there is a relatively strong regulation of the accounting methods for the insurance companies.

The process of describing and analysing the different approaches and models concerning the valuation of insurance companies reveals some problem concerning Hrdý, Ducháčková (2014) model which is based on the combination of the Income Approach, Bond Pricing Model and the Market Comparison Method where each method was represented by the same share. It was discussed if it is right, because averaging different valuation methods could be in contradiction to common valuation practice represented by majority of academicians such as Damodaran (2009) or Mař́k (2007). After some short analysis the solution of this situation was found in the replacement of the same share of this three approaches by the other chosen shares according to the appraiser's decision and according to the results of the financial analysis and according to the results of the so called analysis of internal and external factors. Also the omission some of these three methods could be possible.

\section{References}

Antill, N. (2005). Company Valuation under IFRS Time Series Econometrics. Harriman House. USA.

Cutler, D. R. (2005). A Simple Model to Predict Loss Ratios in the Domestic Loss Property Liability Insurance Industry. Quarterly Journal of Business and Economics, 44(3-4), 129-139. Available at: http://www.jstor.org/stable/40473408

Dammodaran, A. (2012). Investment Valuation. Tools and Techniques for Determining the Value of Any Asset. 3 ed, New Jersey: John Wiley \& Sons, USA. ISBN: 978-1-118-01152-2.

Dammodaran, A. (2009). Valuing Financial Service Firms. [online] in Dammodaran C2009. [Accessed in June 2012]. Available at: http://pages.stern.nyu.edu/ adamodar/

Harrington, S. E., Niegehaus, G. R. (2003). Risk Management and Insurance. McGraw-Hill Companies. ISBN: 978-0072339703.

Hejduková, M. (2009). Specifics of Valuation of Insurance Companies as the Subject of Valuation with the Accent on Financial Analysis. Valuation, 4, 14-28.

Hejduková, M. (2010). The Income Methods of Valuation of Commercial Insurance Companies. Valuation, 3, 16-26.

Hejduková, M. (2010). Property Methods of Valuation of Insurance Companies. Proceedings from International Conference for the young Researchers in Opava, 1196-1204.

Hrdý, M., Ducháčková, E. (2014). Valuation Models of Insurance Companies in Real Economy. Research Journal in Organizational Psychology and Educational Studies. Emerging Academy Resources. India. 357-356.

Hrdý, M., Ducháčková, E. (2010). Basic Principles of Valuation of Insurance Agencies. $E+M$, Economics and Management, 1, 47-59.

Hrdý, M., Ducháčková, E. (2011). The Introduction into Valuation Standards for Insurance Companies. Valuation, Number, 4, 3-17.

Hrdý, M. (2005). Valuation of Financial Institutions. Praha: Grada Publishing. ISBN 80-247-0938-4.

Králík, J. (2007). The Specifics of the Processing of the Financial Analysis, its Possible Modifications and One's Own Application at the Process of the Valuation of the Insurance Company.

Doctoral Dissertation, Liberec. 
Mařík, M. et al. (2007). The Methods of Valuation of the Entreprises. The Process of the Valuation, the Basic Methods and Approaches. Ekopress, s.r.o. ISBN 978-80-86929-32-3.

Massari, M., Gianfrate, G., Zanetti, L. (2014). The Valuation of Financial Companies. Tools and Techniques to Value Banks, Insurance Companies, and Other Financial Institutions. Wiley \& Sons Ltd. ISBN: 978-1-118-61733-5.

Miller, W. D. (1995). Commercial Banks Valuation. John and Sons, Inc., USA. ISBN: 978-0471128205.

Nissim, D. (2013). Relative Valuation of U.S. Insurance Companies, Review of Accounting Studies, 18(2), 324-359, http://dx.doi.org/10.1007/s11142-012-9213-8

Pláničková, M. (2014). The Valuation of the Commercial Insurance Companies with the Aiming to the Market Comparison Methods of Valuation. The Disseration Work. VSE Praha.

Potocký, R., Waldl, H., Stehlík, M. (2014). On Sums of Claims and Their Applications in Analysis of Pension Funds and Insurance Products. Prague Economics Papers, 23(3), 349-370, http://dx.doi.org/10.18267/j.pep.488

Rezaee, Z. (2001). Financial Institutions, Valuations, Mergers, and Acquisitions. Wiley John and Sons., USA. ISBN: 978-0-471-04633-2. 